\title{
STATE FOOD, DRUG AND COSMETIC LEGISLATION AND ITS ADMINISTRATION
}

\author{
Old SAIthe*
}

\section{Why a Uniform State Food, Drug and Cosmettc Act?}

One of the first reactions that will naturally follow the recent adoption of the Federal Food, Drug and Cosmetic Act of x938, will be to consider the advisability of amending the existing state food and drug laws. This, immediately, will raise numerous questions. Many of the states now have good food and drug laws and highly efficient enforcement agencies. Hence, there may be a natural reluctance on their part to amend their laws. Then again, the old question arises as to resentment on the part of state officials and legislators to federal interference and domination, or vice versa. This is always a factor to be reckoned with as both state and federal officials hesitate to act as frankly as they might with each other because of the fear of being misunderstood.

In looking for an answer to some of these questions it should be pointed out that food and drug laws are essentially consumer measures, intended for the protection of public health, and, therefore, no stone should be left unturned to see that the consumer receives this protection. The consumer will receive the greatest amount of this protection when federal, state and municipal food and drug officials cooperate in the enforcement of a uniform law. That is the ball on which all the factors should keep their eyes. As soon as anyone takes his eye off this ball there is bound to be trouble and the consumer suffers.

The part that the courts play in this matter should not be overlooked. It is their decisions that make possible effective enforcement of food and drug laws. It would be of considerable value to a state judge who was trying a particularly troublesome case if he could have the benefit of decisions of courts of other states upon the identical statutory language which was before him for interpretation.

Another factor that plays an important part in the establishment of uniform laws is the attitude of industry. Anyone interested in this question should study the recent experiences in the enactment of the Federal Food, Drug and Cosmetic Act. It took five years to pass that law. A food, drug and cosmetic law is a highly technical

- Consultant to the Food and Drug Administration, United States Department of Agriculture, since October, 1938. Technical adviser to the late United States Senator Royal S. Copeland, 1924-1938. Former director of the Bureau of Food and Drugs, Department of Health, City of New York. 
document. It naturally arouses many conflicting opinions. It was only when these conflicting opinions were satisfactorily reconciled that the law was passed.

In this connection it is only fair to point out that all the zeal for consumer protection does not rest entirely on the side of the official. A large percentage of industry is just as zealous for consumer protection. Therefore, it might be well for the state officials to study carefully the hearings, committee reports and debates that took - place when the Federal Act was being considered by Congress. The experience this would give them would be very helpful in charting their course of action.

Of course, when you deal with government and industry relations, the question of frankness again becomes a factor. The suggestions of industry are frequently looked upon with suspicion, the feeling being that because industry advocates a law there must be a selfish reason, and that the measures they advocate must contain "jokers." In drawing a Uniform State Food, Drug and Cosmetic Act, there are no dangers of "jokers" creeping into it if the Federal Act is followed. This is not a new field of exploration. The die has been set. When all the factors in the food and drug industries, as represented by manufacturers, wholesalers, retailers, colleges and boards of pharmacy, advocate a uniform law based almost word for word upon the federal statute, a big step has been taken towards its passage, and the cooperation of industry should be welcomed by state officials and legislators.

There is no doubt that the interest and attention given by individual consumers and consumer groups to federal food, drug and cosmetic legislation have stimulated industry in furthering its efforts to conform to the new law so as to give the consumer every possible protection against adulterated and misbranded products. It would indeed be unfortunate if state officials and state legislatures failed to take advantage of the existing interest and cooperation of industry to bring about the adoption of uniform state laws, patterned after the new Federal Act, recognizing, of course, any special conditions that may exist in any of the states.

While the new Act is hailed as a progressive step for the consumers of the country, the consumer will only reap the full benefits of this law if there is adequate enforcement. Another benefit which is worthy of consideration is the fact that the administration and enforcement of all food, drug and cosmetic laws could be accomplished at a much lower cost if the federal, state and municipal authorities were working together under uniform laws.

Just how the state officials feel about the matter of a uniform law may be ascertained from the report of Dr. J. J. Taylor, outgoing President of the Association of Food and Drug Officials of the United States, which he presented at the Association's last annual convention in October, 1938. Dr. Taylor reported that he had submitted a questionnaire to the various state food control officials requesting an expression whether or not in their opinion, with the passage of the new Federal Act, it would be necessary for the states to consider new state laws. He grouped his replies into four subdivisions: 
I. Sixty percent of the answers indicated that the state control officials felt that new state legislation was necessary.

2. Officials in five states felt their present laws were adequate, with possible small exceptions.

3. Officials in six states were uncertain whether or not they would need new legislation, and had put the matter up to their legal advisors.

4. Officials in two states counseled caution against acting too precipitately and suggested waiting a year or two to see how the new Federal Act worked out. Their thought seemed to be that in waiting this length of time some weaknesses might be developed that could be corrected by State legislation.

\section{Scope of Existing State Food and Drug Laws}

In considering this problem it will be well to study the existing state laws on food and drug control. All the states, with the exception of New Mexico, now have comprehensive laws regulating the manufacture and sale of adulterated and misbranded food and drugs. The language of the definitive provisions as to adulterated or misbranded food and drugs is practically the same in the state laws as in the definitive provisions of the Federal Food and Drug Act of I906. Variation occurs chiefly with respect to the grant of power to promulgate rules and standards and with respect to narcotics, hypnotics, and cosmetics which have been specially dealt with in laws enacted since Ig06. Accordingly, attention will be directed to these matters rather than to the definitive food and drug provisions.

\section{Power to Promulgate Regulations and Standards}

Most of the state legislatures have delegated to the enforcing officials power to make regulations implementing the state acts. In some states, the power granted is general in character, authority being given to make rules and regulations for carrying out the provisions of the act. In a considerable number of states, however, power is given to adopt definitions of identity and standards of quality and purity for food products. In some, like power is granted with respect to drug products, but more generally the drug standards prescribed in the United States Pharmacopoeia and the National Formulary are specifically adopted, as is done in the Federal Act.

In many states where the law specifically provides that standards be formulated, the law also provides that the standards be in accordance with those promulgated by the Secretary of Agriculture of the United States. This has created a rather peculiar situation because, until the enactment of the Federal Food, Drug and Cosmetic Act of $193^{8}$, the Secretary of Agriculture had no power to promulgate standards. The Secretary did promulgate "advisory" standards (i.e., standards for the guidance of officials and the trade but not having the force and effect of law) and it is these which have been incorporated into those state laws containing the provision described above.

In a number of these laws reference is made to the Food and Drug Act of rgo6. Since this law has been repealed and becomes ineffective after June 25, r939, the state laws in which this reference is made will also have to be amended. 
Detailed treatment of the state legislation on this point is not feasible within the limits of this article, but its content can be generally indicated in the summary which follows.

In 27 states, specific power is given to the appropriate state agency to establish food standards, ${ }^{1}$ and in 16 of these ${ }^{2}$ like authority is given with respect to drugs. Fourteen of the states ${ }^{8}$ require conformity to federal standards, some acts making specific exception of federal standards in conflict with state statutory standards. In Kentucky, ${ }^{4}$ it is provided that where the standard fixed by the state differs from the federal, the State Board of Health shall arrange for a conference with representatives of the United States Department of Agriculture "for the purpose of arriving, if possible, at a uniform state and national standard." Kansas prescribes conformity to the federal standards until different state standards are published. ${ }^{6}$ Oregon $^{6}$ and Rhode Island ${ }^{\top}$ stipulate that the state standards shall not be higher than the federal.

Several of the above states have referred to federal standards in such fashion as to restrict the reference to standards promulgated under the rgo6 Act. In three states, ${ }^{8}$ this is done expressly and in two, ${ }^{9}$ by implication from the fact that the standards referred to are those fixed by the Secretaries of Agriculture, the Treasury, and Commerce and Labor, the three officials upon whom joint rule-making power was conferred by the $x 906$ Act.

Instead of conferring power upon state officials to promulgate standards, 13 states $^{10}$ have incorporated by reference federal standards into the state law. In only two states has this been done with respect to drug as well as food standards. ${ }^{11}$ Two statutes $^{12}$ incorporate only standards fixed under the rgo6 Act. The Vermont act

\footnotetext{
${ }^{1}$ Alabama: CODE (Michie, r928) \$4425; Delaware: Rev. Code (1935) \$4002; Florida: Comp. GeN. LAws (1927) \$3209; Georgia: CoDe (Michic, I933) \$42-III; Illinois: REv. STAT. (1937) c. 561/2, \$\$1, 40; Indiana: Stat. (Baldwin, 1934) \$8476; lowa: CODE (1935) \$3059; Kansas: Gen. Stat. (1935) \$65-613; Kentukky: Stat. (Baldwin, 1936) \$2060a-8; Louisiana: Gen. Stat. (Supp. 1938) \$3317.5; Maine: Rev. Stat. (I930) c. 41, 565; Massachusetts: Anv. Laws (1933) c. 94, 5192; Minnesota: Stat. (Mason, 1927) \$3804; Montana: Rev. Codes (I935) \$\$2591, 2596; Nebraska: Comp. Stat. (I929) 81-902; Neav Jersey: REv. Stat. (1937) \$24:6-1; North Carolina: Code (Michie, 1935) \$4764; North Dakota: Comp. LAws (Supp. x913-1925) \$2889bi8; Ohio: Gen. Code (Page, I937) \$1177-12; Oregon: Code ANN. (1930) \$41II5; Pennsylvania: 3 I Stat. Awn. (Purden, Supp. 1938) §8; Rhode Island: GEN. LAws (1923) \$2389: South Carolina: CODE (1932) \$5125; South Dakota: CoMp. LAws (1929) \$7793; Texas: STAT. (1928) art. 4466(2); Virginia: Code (Michie, 1936) \$1185; Washington: Rev. Star. (Remington, 1932) \$6137. In Oregon, provision is made for the establishment of quality grades of food products, only licensed manufacturers being entitled to use the official grade designations. ORE. CODE ANN. (Supp. 1935) \$\$41-230 41-235.

- Alabama, Delaware, Florida, Indiana, Kansas, Maine, Massachusetts, Montana, New Jersey, North Carolina, North Dakota, Rhode Island, South Carolina, South Dakota, Texas, Washington, all supra note $x$.

Alabama, Delaware, Florida, Georgia, Iowa, Massachusetts, Minnesota, Montana, Nebraska, New Jersey, Ohio, Rhode Island, Virginia, Washington, all supra note $x$.

Supra note $I$.

- Supra note $\mathrm{r}$.

${ }^{5}$ Supra note $\mathrm{x}$.

${ }^{7}$ Supra note $\mathrm{I}$.

${ }^{8}$ Delaware, Montana, Nebraska, all supra note r. 'Alabama, Georgia, both supra note $\mathrm{I}$.

10 Arizona: CODE (Struckmeyer, 1928) c. 61, art. 4; California: GeN. Laws (Deering, 1931) act 57, 53; Idaho: Code (1932) \$36-315; Maryland: Code ANN. (Flack, Supp. 1935) art. 43, \$194; Michigan: CoMp. Laws (1929) \$5443; Mississippi: CODE ANN. (1930) \$4959; Missouri: REv. Stat. (1929) S13019 (10); Nevada: Comp. Laws (Hillyer, 1929) \$6182; New Hampsnire: Pus. Laws (1926) c. 139, \$12; Oklahoma: Stat. (Harlow, 1931) c. 24, art. II; Utah: Rev. Stat. (1933) \$3-10-4; Vermont: Pus. Lawo (r933) tit. 23, c. 221; Wyoming: Rev. STAT. (r93r) \$45-119.

11 Maryland, Mississippi, both supra note ro.

${ }^{12}$ Nevada, New Hampshire, both supra note to.
} 
refers to standards adopted under federal acts passed in 1902 and $1903 .{ }^{13}$ Florida, one of the states which grants power to promulgate standards to its enforcement officials, also provides ${ }^{14}$ for the incorporation into its law of federal statutory standards of which there are very few.

The foregoing types of statutes vary in the manner of their reference to standards. Most frequently, perhaps, the reference is to "standards of quality, purity, and strength." In some instances, "standards of purity" only are mentioned. A number of states. properly add "definitions" or "definitions of identity" to their reference to standards.

It is not always clear from a reading of a given statute whether the standards in question are advisory only or whether they have the force and effect of law. In some instances, the answer to this question is either express ${ }^{15}$ or clearly inferable. ${ }^{16}$

In four states, ${ }^{17}$ where no specific authority to promulgate standards is granted, the enforcing agency is given general power to promulgate rules and regulations. Some of these provisions are couched in language similar to that used in the federal act of 1906 in granting power to make rules and regulations to the three Secretaries mentioned above. Since, under this power, federal advisory standards have been promulgated, it would seem that a similar power would be conferred by the like state provisions, although it may not always have been exercised for this purpose. In two of thése states, ${ }^{18}$ the state agencies are directed to make their rules and regulations conform so far as possible to the federal.

There remain three states ${ }^{19}$ where no rule-making power seems to have been conferred on the enforcing agencies.

\section{The Uniform Narcotic Law}

In advocating the adoption of a Uniform Food, Drug and Cosmetic Law, the experience gained in the adoption of the Uniform Narcotic Law may be helpful. All the states, with the exception of California, Kansas, Maine, Massachusetts, New Hampshire, North Dakota, Pennsylvania, Vermont, and Washington, adopted the Uniform Narcotic Law. ${ }^{20}$ Some of the states made variations in the law. For ex-

\footnotetext{
"supra note no.

${ }^{13}$ Fla, Comp. Gen. Laws (1927) $\$ 321 \mathrm{r}$.
}

${ }^{25}$ Thus, in Indiana, Minnesota, and Montana, all supra note 1 , the statute specifically provides that violation of the standard is punishable, while in North Dakota, supra note 1 , the standards are stated to have the "force and effect of law."

${ }^{10}$ In the states listed in note 17 , infra, it seems clear that the standards would have advisory status only.

ir Arkansas: Stst. (Crawford \& Moses, I921) c. 69; Colorado: Comp. Lnws (I921) \$997; Connecticut: Gen. StAT. (1930) \$2438; New York: LAws (Cahill, 1930) c. I, \$24.

In In Colorado and Connecticut, both supra note I7, the statutes call for conformance to rules and regulations promulgated by the Secretary of Agriculture under the Federal Act of 1906. In most states where specific power to establish standards is granted, power to issue rules in aid of enforcement is also given, subject in a number of instances to the requirement of conformity.

vo Tennessee, West Virginia, and Wisconsin. Wisconsin, however, has comprehensive statutory standards, extending over 14 pages of the Wisconsin statutes. WIs. STat. (1933) \$352.03. Presumably these standards conformed to the federal standards as of the date of their enactment. New Mexico, having no comprehensive act, is not included in the foregoing enumerations.

${ }^{\infty}$ For the text of this act, together with citations to the statutes of the states adopting it and statements of variations from the Uniform Act in various state acts, see 9 UNIF. LAws Asw. (Supp. 1938) 173. 
ample, the penalty clause in all cases is not identical; the repeal clause differs; the department charged with enforcement of the act differs and, in a few states, cannabis is not brought within the provisions of the law.

\section{Hypnotic Drugs}

Nineteen states, Alabama, Arkansas, California, Colorado, Connecticut, Louisiana, Maine, Maryland, Nebraska, Nevada, New Hampshire, New Jersey, North Carolina, Oklahoma, Oregon, Pennsylvania, Rhode Island, South Carolina and Virginia, have adopted special laws regulating and restricting the sale of barbital and other hypnotic drugs. ${ }^{21}$ The sale of such drugs is restricted on a prescription of a legally qualified physician, dentist or veterinarian.

Twenty states, including Alabama, Arkansas, Colorado, Idaho, Kansas, Kentucky, Louisiana, Minnesota, Mississippi, Montana, Nebraska, New Mexico, North Dakota, Oklahoma, Tennessee, Vermont, Virginia and Wyoming have adopted special laws regulating and restricting the sale of marihuana. ${ }^{22}$ Some states prohibit its sale entirely while other states restrict its sale on a prescription of a legally qualified physician, dentist or veterinarian.

\section{Cosmetics}

Comparatively few states have laws regulating the sale of cosmetics.

Florida has a Toilet Articles Misbranding $\mathrm{Law}^{23}$ which, however, merely requires such articles to declare the name and address of the manufacturer on the label when the name of the retail seller appears on the label.

Louisiana has a Cosmetic Law ${ }^{24}$ similar to the new Federal Act. In fact, it was copied from one of the versions of S. 5 which was considered by Congress. It defines adulterated and misbranded cosmetics. It differs from the federal law in that it provides for the registration of each separate product, and a fee for such registration is assessed.

Maine has a Cosmetic Registration $\mathrm{Law}^{25}$ which provides for the registration of all cosmetic preparations sold in the state. The Department of Health is authorized to refuse the issuance of a certificate of registration when in its judgment a cosmetic

1 Alabama: Acts 1935, act no. 236; Arkansas: Acts 1935, acts nos. 113, 327; California: Penas Code (Deering, 193I) \$3471/2; Colorado: Laws 1935, c. 106, \$I; Connecticut: GzN. Stat. (Supp. 1931-35) 5I148c; Louisiana: Gen. Stat. (Supp. 1938) \$3317,9; Maryland: Code AnN. (Flack, x935 Supp.) art. 43, S24rk; Nebraska: Laws 1935, c. 64; Nevada: Comp. LAws (Hillyer, Supp. I938) 5509x.01 (13a); New Hampshire: Laws 1931, c. 123, \$5(II); New Jersey: Laws 1933, c. 279; Oklahoma: Laws r933, c. 77; Oregon: Code ANv. (Supp. 1935) §68-206r; Pennsylvania: 35 PA. Stat. Anv. (Purden, Supp. 1938) 55940-944; Rhode Island: Laws 1937, c. 2542; South Carolina: Stat. (r937) act no. I51; Virginia: Code (Michic, 1936) $551698 \mathrm{a}-1698 \mathrm{c}$.

"Arkansas: Acts 1937, act no. 258; Colorado: Laws 1935, c. 107(13); Idaho: Code (1932) \$36-201; Kansas: Gen. Stat. (1935) \$21-2168; Kentucky: Stat. (Baldwin, 1936) \$2635a-r; Louisiana: GeN. Stat. (Supp. 1938) \$3315.2; Minnesota: Stat. (Mason, Supp. 1936) \$10278-2a; Mississippi: Laws 1938, c. 352; Montana: Rev. CoDes (1935) \$3202.3; Nebraska: Laws 1937, c. 65; New Hampshire: Laws 1935, c. 156; New Jersey: Laws 1938, c. 156; New Mexico: Laws 1935, c. 97; North Dakola: Laws 1933, c. 106; Oklahoma: Laws 1933, c. 24; Tennessee: CoDE ANN. (Williams, Supp. 1938) c. 21A; Virginia: Acts 1936, c. 212; Wyoming: CODE (1931) 585-117. CoNe. GeN. Laws (1927) 57852.

* Acts 1936, 2et no. I42.

sows 1935, c. rog. 
preparation contains injurious substances in such amount as to be poisonous, injurious or detrimental to the person.

North Dakota has a Cosmetic Act. ${ }^{28}$ This law regulates the sale of adulterated and misbranded cosmetics. The provisions are almost identical to the cosmetic provisions of the 1938 Federal Act.

Virginia has a Cosmetic Permit Law. ${ }^{27}$ It prohibits the sale of cosmetics without a permit and defines adulterated and misbranded cosmetics. These provisions are practically the same as the new Federal Act. It also provides that a cosmetic may be manufactured only by a qualified person, approved by the Virginia Board of Pharmacy.

\section{State Enforcement Agencies and Their Powers}

\section{Agencies Charged with Enforcement}

There is no uniformity as to the agencies selected for the enforcement of the food and drug laws in the different states. In 2I states the enforcement of the food law is entrusted to the State Department of Agriculture; in I9 states, to the State Department of Health; in one state, to the Dairy and Food Commissioner; in one state, to the Food Commissioner and Chemist; in one state, to the Food and Drug Commissioner; in one state, to the Department of Justice and Public Safety; in one state, to the State Chemist; in one state, to the State Laboratory; and in two states, to the Department of Welfare.

Insofar as the enforcement of drug laws is concerned, in I3 states this power is delegated to the Department of Agriculture; in two states, to the Dairy and Food Commissioner; in one state, to the Food Commissioner and Chemist; in Ig states, to the State Department of Health; in one state, to the Department of Justice and Public Safety; in one state, to the State Chemist; in two states, to the Department of Welfare; and in nine states, to the State Board of Pharmacy. In many of the states the enforcement is divided among several different departments.

\section{Appropriations}

According to figures submitted in 1937 , in response to a questionnaire, there was a vast difference in the appropriations made for the enforcement of the food and drug laws. The states of New Mexico and West Virginia reported that no funds were made available for food and drug inspection. In two states, Iowa and North Dakota, the fees collected were sufficient to pay the cost of food and drug inspection. Practically all the states have a registration or license plan under which fees are collected. This is a feature on which the greatest resistance is made by industry. Food and drug laws are public health measures and should not be complicated with revenue provisions. If a fee has to be assessed, it might be more just to have it charged in the state where the product is manufactured, for it can be properly argued that the inspection of a factory at regular intervals serves as a check in maintaining the factory at its highest efficiency. If all states and the larger municipalities require

NLaws 1937, c. 136.

"Acts 1938, c. 414. 
that a manufacturer engaged in interstate commerce must pay fees, it may add materially to the cost of the product.

The per capita appropriation for 30 states ranged from 0.24 cents in California to $\mathrm{r} 7.28$ cents per capita in Wyoming. The per capita appropriation of 30 states was as follows:

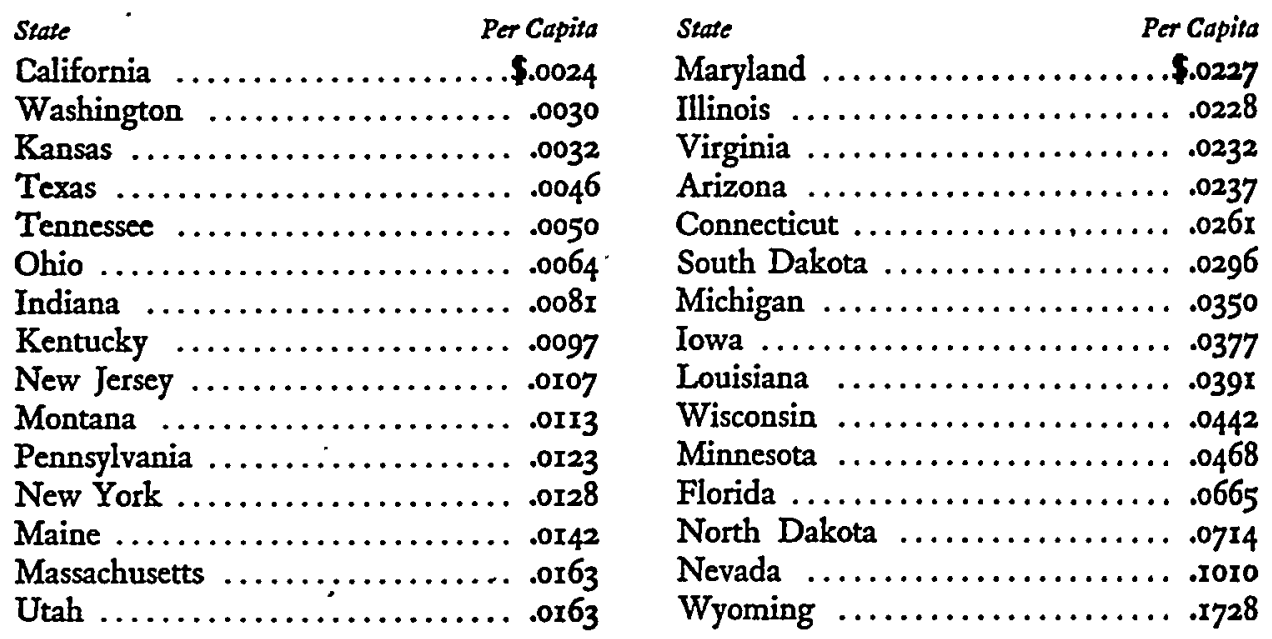

At this point it may be interesting to note that Congress appropriated $\mathrm{r} .33$ cents per capita in 1937 for the enforcement of the Federal Food and Drug Act as compared with $\$ 60.17$ per capita for all governmental expenses.

\section{Powers of Seizure and Condemnation}

While uniformity is highly desirable in the definitive provisions of most of the regulatory provisions of the federal and state laws, it seems advisable to extend the seizure powers of the states. The Federal Food, Drug and Cosmetic control deals primarily with the supervision of food, drugs and cosmetics from the manufacturer to the wholesale.distributor or retail dealer. The state food and drug control deals with the supervision of food, drugs and cosmetics as sold to the consumer. A large percentage of foods are perishable and, for that reason, the powers of the state officials as to seizures and condemnation should be broad. Where foodstuffs are poisonous and actually cause death, prompt action is imperative, as, for example, when some years ago ripe olives were found to contain botulinus bacillus. These olives were responsible for a number of deaths. It was imperative that the state and municipal officials remove the contaminated olives from sale immediately in all retail shops.

Then again, the state food official frequently finds upon examination foods which are actually unwholesome and unfit for human food. This is another instance where his powers should be such that he can take immediate action.

The same is also true of drug products which are found to be actually dangerous to life as, for example, the recent Elixir Sulfanilamide Massengill. During September and October of 1937 at least 73 persons died as a direct result of taking this drug. 
These deaths occurred in $I_{5}$ states, as far east as Virginia and as far west as California. In such cases the powers of the state officials should be sufficiently broad to permit prompt removal of such products from sale.

Under the seizure provisions of the Federal Food, Drug and Cosmetic Act, when any article of food, drug, device or cosmetic is found adulterated or misbranded when introduced into or while in interstate commerce, it is liable to be proceeded against on libel of information and condemnation in any district court of the United States. Under this procedure, the Food and Drug Administration, upon finding an adulterated or misbranded food, drug or cosmetic being shipped in interstate commerce, has to apply to the district court for a libel for condemnation. This is granted immediately, and then is served by an Inspector of the Food and Drug Administration, accompanied by a United States Marshal. While this procedure is satisfactory in federal actions, it is not satisfactory for the states because of the conditions which have been outlined.

At present the state laws do not give definite or specific powers to the state officials to proceed promptly in such instances. The power of seizure is restricted and limited to application to the courts. The widest power on this subject is found in the Sanitary Code of the Department of Health of the City of New York. Section 137 provides as follows:

Condemnation and destruction of animals and foods authorized-Upon any cattle, sheep, swine or any animals, fowl or other birds, meat, fish, vegetables, or milk, or other food or drink being found by any inspector or other duly authorized representative of the Department of Health in a condition which renders it or them, in his opinion unfit for use as human food, or in a condition or of a weight or quality forbidden by provision of the Sanitary Code, such inspector or other duly authorized representative of the said Department is hereby empowered, and directed to immediately condemn, and, when possible, denature the same and cause it or them to be destroyed or removed to the offal or garbage dock for destruction, and report his action to the said Department without delay.

And the owner or person in charge thereof, when so directed by an inspector or other duly authorized representative of the said Department, or by an order of the Sanitary Superintendent, or Assistant Sanitary Superintendent, or the Director of the Bureau of Food and Drugs of the said Department shall remove or cause the same to be removed to the place designated by such inspector or other duly authorized representative, or by the order of said Sanitary Superintendent, or such Assistant Sanitary Superintendent or the Director of the Bureau of Food and Drugs, and shall not sell, offer to sell, or dispose of the same for human food. And when, in the opinion of the Sanitary Superintendent or Assistant Sanitary Superintendent, or the Director of the Bureau of Food and Drugs, and such meat, fish, milk, vegetables, or other food or drink shall be unfit for human food, or any such cattle, sheep, swine, or other animals, or fowl or other birds, by reason of disease, or exposure to contagious disease, shall be unfit for human food, and in an unfit condition to remain near other animals or to be kept alive, the Board of Health may direct the same to be destroyed in such manner as the said Board shall designate.

Trend in Recent Amendments of State Food and Drug Laws

During the five years that the Federal Food, Drug and Cosmetic Act was being considered by Congress, numerous bills were introduced in the various state legis- 
latures. Some of them were substantially copies of the bills considered by Congress from time to time. Some were drafted after a model supplied by professional consumer advocate groups. All differed from one another, and all differed from the Federal Food, Drug and Cosmetic Act as enacted. A few of these measures were adopted.

In 1935 Pennsylvania ${ }^{28}$ introduced special provisions governing hypnotic, analgesic and body-weight reducing drugs. This law requires that the label of such drugs shall specify the name of such drug and the proportion or amount thereof.

In I936 Louisiana passed a food, drug and cosmetic law.29 This was patterned largely after an earlier print of S. 5 considered by Congress. A registration feature, whereby products must be registered at a fee of $\$ 5.00$ per product, not to exceed in the aggregate of $\$ 100.00$ was provided. In sincerely attempting to have the state law conform to the federal law, the drafters of the law provided that a food, drug, or cosmetic is adulterated or misbranded "if it has been found to be such by a Department of the United States Government"; not "adjudicated," just "found," 30 and by any "Department of the United States Government," thereby including the Departments of State, War, Navy, Army, etc.

In I937 North Dakota ${ }^{31}$ amended its food and drug law, adopting some of the provisions which were considered by Congress, notably that a drug is misbranded "unless the label shows the name of each active ingredient," and "if it is dangerous to health when used in the dosage or with the freqeuncy or duration prescribed in the labeling or advertising thereof."

In I937 Pennsylvania ${ }^{32}$ amended the law defining adulterated and misbranded food and drugs.

In $193^{8}$ Virginia enacted a new law ${ }^{33}$ regulating the sale of adulterated and misbranded drugs and cosmetics and the false advertising thereof. A number of the provisions of this act were derived from provisions considered by Congress.

Problems in Preparing a Uniform Statute Based on the Frderal Act

In drafting a Uniform State Food, Drug and Cosmetic Act, it is highly desirable that the form of the Federal Act be followed. This would simplify the comparison of the law for the legislator, the official, the courts, the representative of industry or any other interested person. If there is any suspicion that "jokers" might creep into a Uniform State Law, the best check would be to have the state law follow the exact form of the federal law, so that any changes made would be readily ascertainable.

The Federal Food, Drug and Cosmetic Act of 1938 is longer, more intricate and contains more regulatory control than did the Food and Drug Act of rgo6. There are provisions which have to be rounded out by administrative regulations. Therefore, the new law cannot be simply "copied." When the state legislatures delegate

\footnotetext{
$\$$ L2ws 1935, act no. 407 . $\quad{ }^{20}$ La. Acts 1936, act no. 142.
}

${ }^{\circ} \mathrm{Cf}$. the language used in the Virginia act, Acts 1938, c. 375, \$1663(1): "If it has been adjudicated to be such [i.e., adulterated] by final judgment under the Food and Drug Act of the United States."

I Laws 1937, c. 375 .

- Laws 1937, act no. 291.

$\therefore$ Laws 1938, c. 375. 
power to state officials to promulgate regulations there should be some definite provision for uniformity of action with the federal laws, so as to eliminate the confusion that would result in trying to comply with conflicting control. To avoid this situation, it will be necessary to make provisions such as either (a) exempting from the adulteration and misbranding provisions of the state laws an article in interstate commerce which complies with the federal law, or (b) providing in the state laws that the regulations of the federal government will be adopted by the states.

It is also important that a Uniform State Law contain a preamble or section indicating the intent of the law. If the intent is to be uniformity, then it should be so stated in the law. This would be helpful to the courts in interpreting the law. In rendering decisions relating to Federal Food and Drug Act of 1906 , the courts have considered the intent of Congress. ${ }^{34}$

The Federal Food, Drug and Cosmetic Act of 1938 might be used as a basis for a state law with relatively few changes of substance, although a number of formal changes would have to be made. It is suggested that the same section numbers, or at least the same sequence of sections, be used in the state act as are used in the federal. Assuming the same section numbers to be used, the changes from the Federal Act which would be desirable are the following:

I. Wherever in the Federal Act reference is made to the Secretary of Agriculture, this term should be eliminated and the title of the state official or agency charged with the enforcement of the state act substituted.

2. Where power is given in the Federal Act to the Secretary to promulgate regulations, the grant of this power to the corresponding state official should be qualified by a proviso reading as follows: "provided, that the regulations so promulgated shall conform, so far as possible, to the regulations prescribed by the Secretary of Agriculture of the United States under Section - of the Federal Food, Drug, and Cosmetic Act."

In certain situations, it seems preferable that the federal regulations be adopted directly in lieu of conforming state regulations or unless and until state regulations be promulgated. The provisions suggested for these situations follow:

(a) Chapter 5, \$50I. This section defines the term "Adulterated Drugs and Devices." It is suggested that the following be substituted for the second sentence in paragraph (b) of this section: "Such determination as to strength, quality, or purity shall be made in accordance with the tests or methods of assay set forth in such compendium or prescribed by the Secretary of Agriculture of the United States, in regulations promulgated under Section 5or(b) of the Federal Food, Drug, and Cosmetic Act."

(b) Chapter 5, \$502. This section defines the term "Misbranded Drugs and Devices." In paragraph (d), dealing with habit-forming drugs, after the words "such substance," include the following: "which derivative has been by the [designated official], after investigation, found to be, and by regulations under this Act, or by regula-

"See, e.g., U. S. v. Lexington Mill \& Elevator Co., 232 U. S. 399 (19I4). 
tions promulgated by the Secretary of Agriculture of the United States under Section 502(d) of the Federal Food, Drug, and Cosmetic Act."

In paragraph (g), dealing with the packaging requirements of "official" drugs, substitute for the words "That the method of packing may be modified with the consent of the Secretary" the following: "That the method of packing may be modified with the consent of the [designated official] in accordance with regulations promulgated by the Secretary of Agriculture of the United States under Section 502(g) of the Federal Food, Drug, and Cosmetic Act."

For paragraph (h), dealing with deteriorating drugs, substitute the following: "If it has been found by the Secretary of Agriculture of the United States or the [designated official] to be a drug liable to deterioration, unless it is packaged in such form and manner, and its label bears a statement of such precautions, as the' Secretary of Agriculture of the United States or the [designated official] shall by regulations require as necessary for the protection of public health. No such regulation shall be established for any drug recognized in an official compendium until the Secretary of Agriculture of the United States or the [designated official] shail have informed the appropriate body charged with the revision of such compendium of the need for such packaging or labeling requirements and such body shall have failed within a reasonable time to prescribe such requirements."

3. Chapter I, $\$$. This section contains the short title of the Act for purposes of citation. In the state act this should be the "Uniform State Food, Drug, and Cosmetic Act." This chapter should also contain a new section which would declare the legislative intent that the law shall be uniform with the Federal Food, Drug and Cosmetic Act, and that the regulations promulgated under the state act will maintain uniformity with the regulations promulgated under the Federal Act.

4. Chapter II, \$20I. This section contains definitions. Paragraph (a) defining "territory," paragraph (b) defining "interstate commerce," and paragraph (c) defining "department" should be deleted. A definition designating the state official, board or department charged with the enforcement of the state act should be substituted for paragraph (c).

5. Chapter III, \$30r. This section defines the acts prohibited by the statute. All the paragraphs of this section could be used as written with exception of paragraphs (a) and (d). These paragraphs should be amended to read so as to prohibit "the manufacturing, keeping, having, selling or offering for sale, or bringing into the State." A new paragraph should be added providing for articles embargoed or quarantined.

6. Chapter III, $\$ 303$. This section provides for penalties. This of course should be included, but the penalties should be left to the discretion of each state legislature. This section also provides for an exemption from penalty when a guaranty or undertaking can be established. This section should be included in the state law.

7. Chapter III, \$304. This section provides for the seizure of food, drugs, devices, or cosmetics that are adulterated or misbranded. A similar provision should be in- 
cluded in the state law following the principles of this section, but it should also provide for the immediate condemnation and destruction of unwholesome food unfit for human consumption, and drug or cosmetic products that are actually dangerous to life.

8. Chapter III, $\$ 307$. The name of the enacting state should be substituted for "the United States" in this section.

9. Chapter $V, \$ 505$. This section prescribes the procedure whereby producers of "new drugs" shall make application for the introduction of such drugs into commerce, the information to be filed therewith, the grounds for refusing the application, and the judicial review of the Secretary's order. In lieu of this section in the Federal Act, the substitution of the following, briefer section is suggested:

"Section 505(a) No person shall sell, deliver, offer for sale, hold for, sale, or give away any new drug, unless $(\mathrm{I})$ an application with respect thereto has become effective under Section 505 of the Federal Food, Drug, and Cosmetic Act, or (2) when not subject to the Federal Food, Drug, and Cosmetic Act, unless such drug has been tested and has not been found to be unsafe for use under the conditions prescribed, recommended, or suggested in the labeling thereof, and prior to selling or offering for sale such drug, there has been filed with the [designated official] an application setting forth (a) full reports of investigations which have been made to show whether or not such drug is safe for use; (b) a full list of the articles used as components of such drug; (c) a full statement of the composition of such drug; (d) a full description of the methods used in, and the facilities and controls used for, the manufacture, processing, and packing of such drug; (e) such samples of such drug and of the articles used as components thereof as the [designated official] may require; and (f) specimens of the labeling proposed to be used for such drug.

(b) An application provided for in subsection (a) (2) shall become effective on the 6oth day after the filing thereof, except that if the [designated official] finds after due notice to the applicant and giving him an opportunity for a hearing, that the drug is not safe for use under the conditions prescribed, recommended or suggested in the proposed labeling thereof, he shall, prior to the effective date of the application, issue an order . refusing to permit the application to become effective.

(c) A drug dispensed on a written prescription signed by a physician, dentist, or veterinarian (except a drug dispensed in the course of the conduct of a business of dispensing drugs pursuant to diagnosis by mail), shall be exempt from the requirements of Section 505 if-(I) such physician, dentist, or veterinarian is licensed by law to administer such drug, and (2) such drug bears a label containing the name and place of business of the dispenser, the serial number and date of such prescription, and the name of such physician, dentist, or veterinarian.

(d) The [designated official] shall promulgate regulations for exempting from the operation of this section drugs intended solely for investigational use by experts qualified by scientific training and experience to investigate the safety of drugs and labeled "For Investigational Use Only."

ro. Chapter VII, \$7or. This section authorizes the Secretary to promulgate regulations for the enforcement of the Act, provides for hearings thereon, and prescribes a special proceeding for the judicial review thereof. It is suggested that the special review proceeding be deleted in the state act, leaving the regulations to be reviewed in the state courts in accordance with the principles of judicial review of administra- 
tive action developed in each enacting state. In addition to formal changes, it is further suggested that the following changes be made in this section:

(a) Delete paragraph (b) dealing with regulations relating to imports, paragraph (c) relating to the official conducting hearings, and paragraph (d) relating to standards contained in other federal laws.

(b) Add a new paragraph (b) reading as follows: "(b) The purpose of this Act being to promote uniformity with the Federal Food, Drug, and Cosmetic Act, the [designated official] is hereby authorized to adopt, insofar as applicable, the regulations from time to time promulgated by the Secretary of Agriculture of the United States under the Federal Food, Drug, and Cosmetic Act."

(c) Revise the first part of paragraph (e), dealing with hearings on regulations, to read as follows: "(c) Except to the extent that the [designated official] adopts the applicable regulations from time to time promulgated by the Secretary of Agriculture of the United States under the Federal Food, Drug, and Cosmetic Act, the [designated official] or such officer or employee as he may designate for the purpose, shall hold a public hearing."

(d) Delete the exception clause from paragraph (e) relating to the time of hearings on regulations under Section 404(a).

(e) Revise paragraph (g) to read as follows: "(d) A certified copy of the transcript of the record and proceedings under subsection (c) shall be furnished by the [designated official] to any interested party at his request, and payment of the costs thereof, and shall be admissible in any criminal, libel for condemnation, or other proceeding arising under or in respect to this Act."

II. Chapter VIII. This chapter deals with exports and imports, a matter under exclusive federal jurisdiction, and hence it should be deleted.

I2. Chapter IX, \$902. This section deals with the effective date of the Act and with repeals. Its revision would depend on the nature of other legislation in the enacting state relating to food, drugs, and cosmetics. In this chapter a new section reading as follows should be inserted:

"This Act and the promulgations hereunder shall be so interpreted and construed as to effectuate its general purpose to enact state legislation uniform with the Federal Act." 